\title{
A quantitative study of immunoglobulin containing cells in the differential diagnosis of acute colitis
}

\author{
JP VAN SPREEUWEL,${ }^{*} \dagger$ J LINDEMAN, $\ddagger$ CJLM MEIJER $§$
}

From the *Department of Internal Medicine, Division of Gastroenterology, St Antonius Hospital, Nieuwegein, The Netherlands, the $\ddagger$ Department of Pathology, Stichting Samenwerking Delftse Ziekenhuizen, Delft, The Netherlands, and the §Department of Pathology, Free University, Amsterdam, The Netherlands

SUMMARY In colonic biopsies of 33 patients with acute colitis caused by campylobacter, salmonella, or shigella immunoglobulin containing cells were determined quantitatively using an indirect immunoperoxidase technique and morphometry with a graphic tablet. The findings were compared with those of 10 patients without histological abnormalities, 10 patients with Crohn's disease of the colon, and 10 patients with ulcerative colitis. Biopsies of patients with acute infectious colitis had increased numbers of $\operatorname{IgA}$ containing cells and to a lesser extent $\operatorname{IgM}$ containing cells but not IgG containing cells compared with controls. Compared with the patients with active chronic idiopathic inflammatory bowel disease the patients with acute colitis showed significantly lower relative and absolute numbers of IgG containing cells. We therefore conclude that quantitative assessment of immunoglobulin containing cells in colonic biopsies may be useful in the differential diagnosis of acute infectious colitis and chronic idiopathic inflammatory bowel disease.

Several micro-organisms produce acute self limited colitis with frequent, often bloody, loose stools, crampy abdominal pain, and constitutional symptoms such as fever. The diagnosis can usually be made on the basis of symptoms and stool culture. Although the disease is usually self limiting, in some patients it runs a more prolonged course with remissions and exacerbations resembling chronic inflammatory bowel disease.' In other patients preexisting gastrointestinal complaints suggest underlying disease. In these patients and in those in whom stool cultures fail to reveal enteropathogenic micro-organisms endoscopy with mucosal biopsy is an important tool in the differential diagnosis. Histologically, differentiation between acute and chronic colitis may be difficult, especially in the later stages, when histological abnormalities are less specific and the inflammatory infiltrate in the colonic mucosa consists mainly or solely of mononuclear cells. ${ }^{2}$ This may erroneously lead to a histological

†Present address: Department of Internal Medicine, Division of Gastroenterology, Hospital St Annadal, Maastricht, The Netherlands.

Accepted for publication 25 January 1985 diagnosis of chronic inflammation and unnecessary treatment.

We have examined morphometrically the numbers of $\operatorname{IgA}, \operatorname{IgM}, \operatorname{IgG}$, and $\operatorname{IgE}$ containing cells in colonic biopsies from patients with acute infectious colitis and compared our findings with those in patients with Crohn's disease of the colon or ulcerative colitis and healthy controls in order to determine its value in the differential diagnosis of acute infectious and chronic idiopathic colitis.

\section{Patients and methods}

\section{PATIENTS}

Four groups of patients were studied.

1 Thirty three patients with acute infectious colitis, caused by campylobacter ( 22 patients), salmonella (6 patients), and shigella ( 5 patients). One patient had a long standing history of ulcerative colitis and $\stackrel{\varrho}{C}$ another patient had suffered from idiopathic proctitis several years previously. The others had no coexisting gastrointestinal disease.

2 Ten control patients without any sign of colitis in whom colonoscopy was performed because of $\frac{\rho}{\mathbb{Q}}$ polyps or the irritable bowel syndrome.

3 Ten patients with ulcerative colitis. The diagnosis 
was based on clinical, radiological, endoscopical, and histological findings. ${ }^{3}$ All patients had a severely inflamed rectal and sigmoid mucosa. Seven patients were treated with sulphasalazine, in combination with topical corticosteroids in three patients.

4 Ten patients with Crohn's disease of the colon. All patients had active disease and inflammatory changes in their colonic biopsies. The diagnosis was based on the history and radiological, endoscopical, and histopathological findings. ${ }^{34}$ Seven patients were treated with sulphasalazine, in combination with corticosteroids in three patients.

\section{METHODS}

Stools were cultured for salmonella, shigella, campylobacter, and yersinia routinely. Campylobacter was cultured on a selective medium: blood-agar plates containing Campylobacter Growth Supplement and Campylobacter Selective Supplement (Oxoid LTS, Basingstoke, England, nos SR 84 and SR 85). Inoculated plates were incubated for $48 \mathrm{~h}$ at $42^{\circ} \mathrm{C}$ in an atmosphere containing $5-15 \%$ oxygen and $5-8 \% \mathrm{CO}_{2}$ by using the GasPak of $\mathrm{BBL}$ without a catalyst in a jar.

Biopsies were fixed in a formalin-sublimate mixture for 4-6 h. Tissue samples were embedded in paraplast, cut in sections $4 \mu \mathrm{m}$ thick, and mounted on glass slides. Sections were stained with haematoxylin and eosin and periodic acid Schiff and also for IgA, IgM, IgG, and IgE heavy chains using an indirect immunoperoxidase technique..$^{5}$ Appropriate controls were included. ${ }^{6}$ Rabbit antisera against IgA, IgM, and IgG heavy chains were purchased from Dakopatts (Denmark); rabbit antisera against IgE was obtained from the Central Laboratory of the Netherlands Red Cross Laboratory, Amsterdam. Their specificities were confirmed by immunoelectrophoresis, immunofluorescence, and immunoperoxidase stainings on bone marrow preparations monoclonal for $\operatorname{IgA}, \operatorname{IgM}, \mathrm{IgG}$, and $\mathrm{IgE}$. Horseradish peroxidase labelled goat antirabbit IgG was obtained from Miles (Yedah, Israel). The IgA, IgM, and IgG stained sections were used for morphometric analysis. They were photographed with a standard magnification $(100,8 \times)$ and projected on to a graphic tablet interfaced to a computer (IBASI, Kontron, Munchen).

The lamina propria was limited by two lines perpendicular to the muscularis mucosae, and in this field the lamina propria area was measured per millimetre of muscularis mucosae length. The numbers of cells containing immunoglobulin subclasses were counted in two consecutive sections in roughly the same area of the above mentioned fields and expressed per $0.1 \mathrm{~mm}^{2}$ lamina propria, as an expression of the density, and per $0.5 \mathrm{~mm}$ muscularis mucosae, as an expression of total number of immunoglobulin containing cells. The processed sections contained from 0.5 to $1.0 \mathrm{~mm}$ muscularis mucosae. In the patients with salmonella and shigella colitis biopsies were not properly orientated and so sections could not be cut perpendicular to the muscularis mucosae. Since expression of immunoglobulin containing cells per $0.5 \mathrm{~mm}$ muscularis mucosae would yield an incorrect estimate of the total number of cells, immunoglobulin containing cells were only expressed per $0 \cdot 1 \mathrm{~mm}^{2}$ lamina propria area in these patients.

Statistical analysis was performed according to Wilcoxon's rank test; $\mathrm{p}<0.01$ was considered significant.

\section{Results}

Figures 1 and 2 show the numbers of $\operatorname{IgA}, \operatorname{IgM}$, and IgG containing cells. IgE containing cells were found sporadically and are therefore not included.

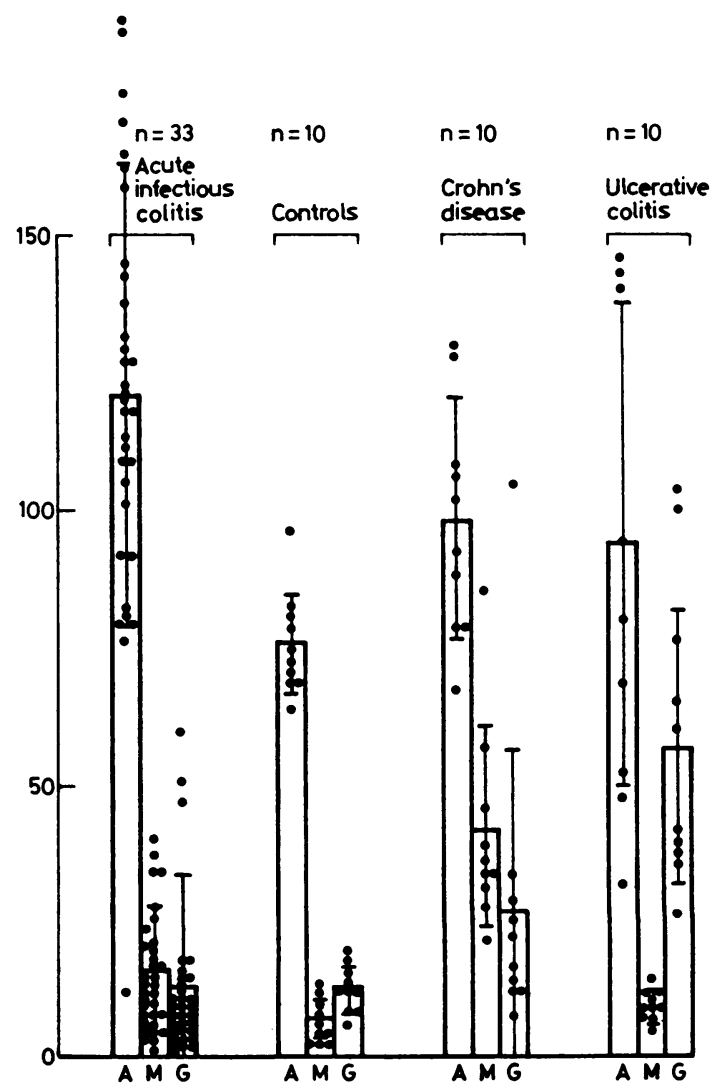

Fig. 1 Number of immunoglobulin containing cells per $0 \cdot 1$ $\mathrm{mm}^{2}$ lamina propria area (mean $\left.\pm S D\right)$. $A=I g A$, $M=I g M, G=I g G$. 


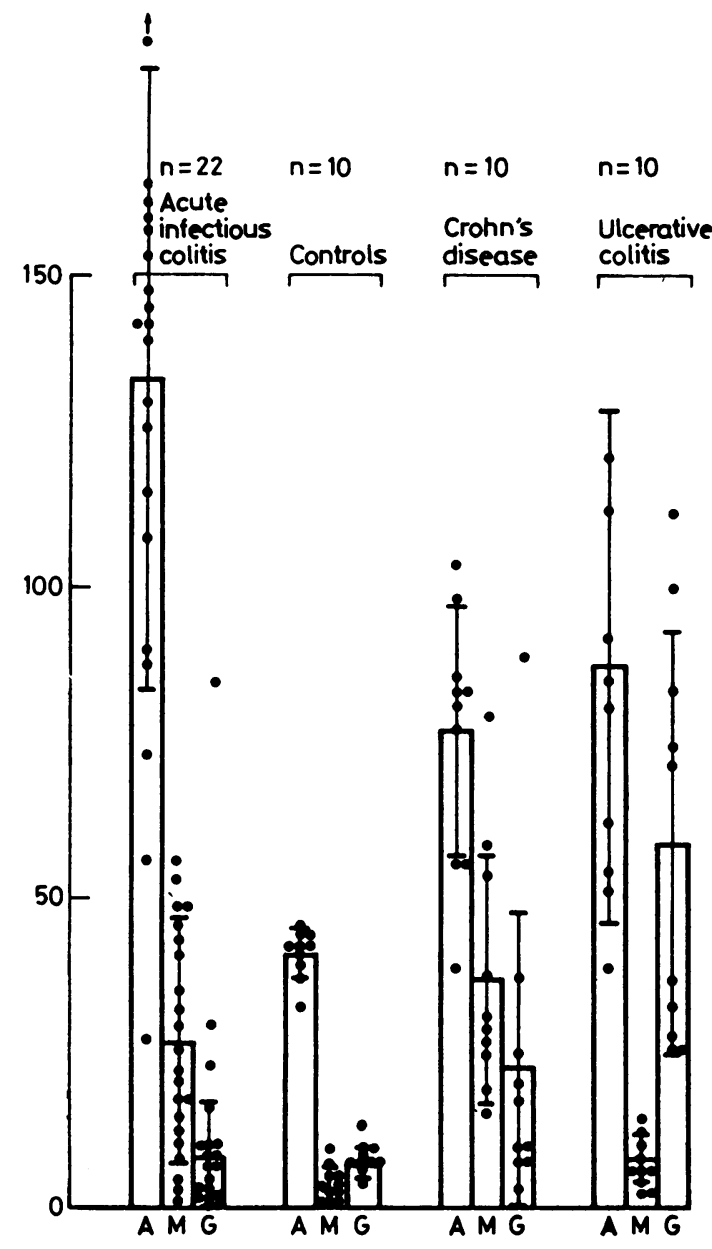

Fig. 2 Number of immunoglobulin containing cells per 0.5 $\mathrm{mm}^{2}$ muscularis mucosae (mean $\pm S D$ ). $A=I g A$, $M=I g M, G=I g G$.

The total number of immunoglobulin containing cells was higher in patients with acute infectious colitis compared with controls. This increase was mainly due to IgA containing cells. The number of IgA containing cells per $0.1 \mathrm{~mm}^{2}$ lamina propria area and per $0.5 \mathrm{~mm}$ muscularis mucosae differed significantly $(p=0.0001$ and $p=0.0003$ respectively). The number of IgM containing cells per 0.5 $\mathrm{mm}$ muscularis mucosae was also increased $(\mathrm{p}=$ 0.001 ), but the number of IgG containing cells did not differ. Nevertheless, in three patients with acute infectious colitis an increase in the number of IgG containing cells was found. One patient had campylobacter colitis superimposed on ulcerative colitis and two patients had acute infectious colitis caused by salmonella and shigella which ran a protracted course ( $>14$ days). Biopsies from patients with acute infectious colitis differed significantly from biopsies from patients with chronic inflammatory bowel disease with respect to the number of IgG containing cells (Table). The number of IgG containing cells in colonic biopsies from patients with acute infectious colitis was significantly lower compared with patients with chronic inflammatory bowel disease, both per $0 \cdot 1 \mathrm{~mm}^{2}$ lamina propria area $(p=0.00003)$ and per $0.5 \mathrm{~mm}$ muscularis mucosae $(p=0.00007)$.

\section{Discussion}

In this study colonic biopsies from patients with acute infectious colitis contained significantly increased numbers of IgA containing cells compared with controls. The numbers of IgG containing cells did not differ. Compared with biopsies of patients with active ulcerative colitis and Crohn's disease of the colon the numbers of IgG containing cells in biopsies from patients with acute infectious colitis were significantly lower.

Our findings are in good agreement with a previous study of immunoglobulin containing cells in jejunal biopsies from patients with acute enteritis, which showed an increase of $\operatorname{IgA}$ and IgM containing cells. ${ }^{7}$ Scott et $a^{8}$ found an increase of both $\operatorname{IgA}$ and IgE containing cells in colonic biopsies from patients with acute infectious colitis. But they also found exceptionally high numbers of IgE containing cells in healthy controls.

We conclude from our study that determining the o numbers of $\operatorname{IgA}$, IgM, and IgG containing cells in

Significance of the differences between the groups of patients studied ( $p$ values)

\begin{tabular}{|c|c|c|c|c|}
\hline \multirow[t]{2}{*}{ colitis } & \multicolumn{2}{|c|}{ Acute infectious colitis $v$ controls } & \multicolumn{2}{|c|}{$\begin{array}{l}\text { Acute infectious colitis } v \text { Crohn's disease and ulcerative } \\
\text { colitis }\end{array}$} \\
\hline & $\begin{array}{l}\text { No of cells per } 0.1 \mathrm{~mm}^{2} \\
\text { lamina propria }\end{array}$ & $\begin{array}{l}\text { No of cells per } 0.5 \mathrm{~mm} \\
\text { muscularis mucosa }\end{array}$ & $\begin{array}{l}\text { No of cells per } 0.1 \mathrm{~mm}^{2} \\
\text { lamina propria }\end{array}$ & $\begin{array}{l}\text { No of cells per } 0.5 \mathrm{~mm} \\
\text { muscularis mucosa }\end{array}$ \\
\hline $\begin{array}{l}\text { IgA } \\
\text { IgM } \\
\text { IgG }\end{array}$ & $\begin{array}{l}0.00019^{*} \\
0.033 \\
0.035\end{array}$ & $\begin{array}{l}0.00034^{*} \\
0.001^{*} \\
0.59\end{array}$ & $\begin{array}{l}0.04 \\
0.20 \\
0.00003^{*}\end{array}$ & $\begin{array}{l}0.004^{*} \\
0.57 \\
0.00007^{*}\end{array}$ \\
\hline *Significant. & & & & \\
\hline
\end{tabular}


colonic biopsies helps to differentiate acute infectious colitis from active chronic idiopathic inflammatory bowel disease. Caution is necessary in patients with acute infectious colitis that runs a protracted course since the number of IgG containing cells in colonic biopsies from these patients may be increased, as in patients with active chronic inflammatory bowel disease. For correct interpretation knowledge of the time lapse between the onset of symptoms and biopsy is therefore essential. Although the histological features of acute infectious colitis have recently been outlined more precisely, ${ }^{2910}$ we believe that immunohistochemical characterisation of different subclasses of plasma cells in colonic biopsies provides a useful additional criterion in the differential diagnosis of acute infectious colitis and active chronic idiopathic inflammatory bowel disease.

The authors thank Mrs DIM de Jong for typing the manuscript.

\section{References}

' Blaser MJ, Berkowitz IO, La Force FM, Cravens J, Reller LB, Wang WLL. Campylobacter enteritis: Clincial and epidemiological features. Ann Intern Med 1979;91:179-85.

${ }^{2}$ Spreeuwel JP van, Duursma GC, Meijer CJLM, Bax R, Rosekrans PCM, Lindeman J. Campylobacter colitis. Histological, immunohistochemical and ultrastructural findings. Gut (in press).

${ }^{3}$ Morson BC. The technique and interpretation of rectal biopsies in inflammatory bowel disease. In: Sommers SC, ed. Pathology annual. New York: Appleton-Century-Crofts, 1974:209-30.

4 Whitehead R. Mucosal biopsy of the gastrointestinal tract. London: WB Saunders, 1973:139-66.

s Spreeuwel JP van, Lindeman J, Wal AM van der, Weterman I, Kreuning J, Meijer CJLM. Morphological and immunohistochemical findings in upper gastrointestinal biopsies of patients with Crohn's disease of the ileum and colon. J Clin Pathol 1982;35:934-40.

- Sternberger L. Immunohistochemistry. Englewood Cliffs: Prentice Hall, 1979:53.

' Soltoft J, Sreberg B. Immunoglobulin containing cells in the small intestine during acute enteritis. Gut 1972;13:535-8.

${ }^{8}$ Scott BB, Goodall A, Stephenson P, Jenkins D. Rectal mucosal plasma cells in inflammatory bowel disease. Gut $1983 ; 24: 519-24$.

9 Kumar NB, Nostrant TT, Appleman HD. The histopathologic spectrum of acute self-limited colitis (acute infectious-type colitis). Am J Surg Pathol 1982;6:523-9.

"Surawicz CM, Belic L. Rectal biopsy helps to distinquish acute self-limited colitis from idiopathic inflammatory bowel disease. Gastroenterology 1984;86: 104-13.

Requests for reprints to: Dr JP van Spreeuwel, Department of Internal Medicine, Division of Gastroenterology, Hospital St Annadal, St Annadal 1, Maastricht, The Netherlands. 